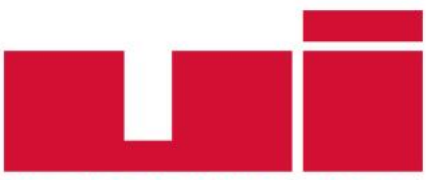

ULUSLARARASIILIȘKiLER

Akademik Dergi

Yayın ilkeleri, izinler ve abonelik hakkında ayrıntılı bilgi:

E-mail: bilgi@uidergisi.com.tr

Web: www.uidergisi.com.tr

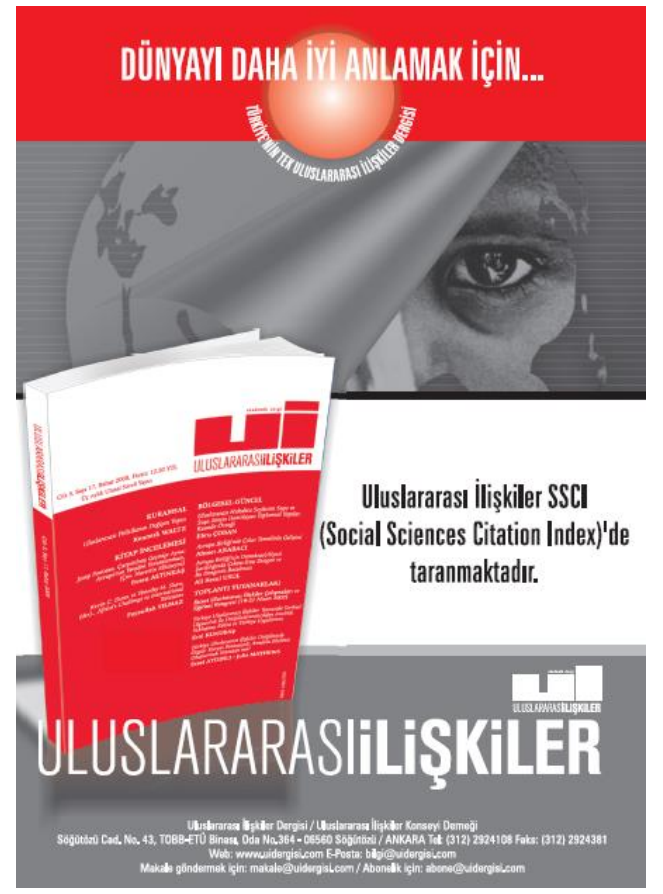

\title{
İskoç Milliyetçiliğinin Dünü, Bugünü ve Birleşik
} Krallı̆̆ın Geleceğgi

\author{
İbrahim SAYLAN* \\ * Yrd. Doç. Dr., Uluslararası İlişkiler Bölümü, Dokuz Eylül \\ Üniversitesi
}

Bu makaleye atıf için: Saylan, İbrahim, "İskoç Milliyetçiliğinin Dünü, Bugünü ve Birleşik Krallığın Geleceği”, Uluslararası İlişkiler, Cilt 14, Sayı 53, 2017, s. 91-109.

Bu makalenin tüm hakları Uluslararası İlișkiler Konseyi Derneği'ne aittir. Önceden yazılı izin alınmadan hiç bir iletişim, kopyalama ya da yayın sistemi kullanılarak yeniden yayımlanamaz, çoğaltılamaz, dağıtılamaz, satılamaz veya herhangi bir şekilde kamunun ücretli/ücretsiz kullanımına sunulamaz. Akademik ve haber amaçlı kısa alıntılar bu kuralın dışındadır.

Aksi belirtilmediği sürece Uluslararası Illişkiler'de yayınlanan yazılarda belirtilen fikirler yalnızca yazarına/yazarlarına aittir. UİK Derneğini, editörleri ve diğer yazarları bağlamaz. 


\title{
İskoç Milliyetçiliğinin Dünü, Bugünü ve Birleşik Krallığın Geleceği
}

\author{
İbrahim SAYLAN \\ Yrd. Doç. Dr., Uluslararası İlişkiler Bölümü, İsletme Fakültesi, Dokuz Eylül Üniversitesi, İzmir. \\ E-posta:ibrahim.saylan@deu.edu.tr
}

\section{ÖZET}

Avrupa'da son yıllarda kayda değer bir siyasal güce dönüşen devlet-altı milliyetçilik Avrupa Birliği üyesi pek çok devlette statükoya meydan okumaktadır. Avrupa bütünleşme süreci ise sadece ev sahibi devlet ile devletaltı milliyetçilik arasındaki siyasi mücadele sahasını genişletmekle kalmamakta, aynı zamanda ulus-devletin ve milliyetçiliklerin yeni koşullar altında değişen özellikleri, işlevleri ve kalıcılık ihtimalleri üzerine tartışmaları tetiklemektedir. 1990'lardan beri yükselişte olan İskoç milliyetçiliğinin başat aktörü İskoç Ulusal Partisi’nin “Avrupa Birliği içinde bağımsızlık" amacı gütmesi, bir yandan devlet altı milliyetçilikler açısından Avrupa bütünleşme sürecinin kritik önemine işaret ederken, öte yandan bağımsız ulus-devlet kurmanın devlet-altı milliyetçilik açısından sonul hedef olma özelliğini koruduğunu göstermektedir. İskoç milliyetçiliği Birleşik Krallığın geleceği konusunda ciddi belirsizlikler yaratırken, bütünleşme sürecinin ulus-devlet modeli ve milliyetçilikler üzerindeki dönüştürücü etkisinin asal nitelikte olmadığını kanıtlamaktadır.

Anahtar Kelimeler: İskoç Milliyetçiliği, Birleşik Krallık, Avrupa Birliği, Fırsat Yapıları.

\section{The Past and Present of Scottish Nationalism and the Future of the United Kingdom}

\begin{abstract}
Having recently become a noticeable political power in Europe, sub-state nationalism challenges status quo in many EU member states. European integration process has not only expanded the arena of political struggle but also triggered debates over changing characteristics, functions and persistence of nation-state and nationalisms under new circumstances. The fact that Scottish National Party as the dominant actor of Scottish nationalism pursues "independence in Europe" confirms both the evident importance of European integration process and the continued significance of independent statehood as the ultimate goal for sub-state nationalisms. Thus, bringing about critical uncertainties about the future of the UK, Scottish nationalism shows that transformative impact of European integration on nation-state model and nationalisms is far from being fundamental.
\end{abstract}

Keywords: Scottish Nationalism, United Kingdom, European Union, Opportunity Structures. 


\section{Giriş}

Uzun bir geçmişi olan devlet-altı milliyetçilik ${ }^{1}$ (sub-state nationalism), Avrupa bağlamında 1960'larla önem kazanan, AB bütünleşme sürecinin de etkisiyle özellikle 1980'lerden bu yana siyasal arenada kendini daha da güçlü şekilde hissettiren siyasal bir olgudur. Birleşik Krallık (BK) devlet-altı milliyetçi hareketlerin eylem ve etkilerine en açık ülkelerden biri olmuştur. Uzun süre şiddet boyutu da içeren Kuzey İrlanda’daki İrlanda milliyetçiliği, kültürel ve dilsel talepleri ağır basan Gal milliyetçiliğinin yanı sıra, İskoç milliyetçiliği bir "birlik devleti” olarak kurulan BK’nin geleneksel siyasal yapısında hâlihazırda önemli değişiklikler yaratmışlardır. Bu milliyetçilikler arasında, bağımsızlık hedefiyle hareket eden, BK'yi 2014 Eylülünde yapılan İskoçya Bağımsızlık Referandumuna zorlayan İskoç milliyetçiliği ve onun başat temsilcisi SNP, Britanya siyaseti ve toplumunun geleceği ile ilgili bir dizi soru ve sorunu siyasal tartışma ve rekabetin konusu haline getirerek ön plana çıkmıştır. $A B$ bütünleşme sürecini bir fırsat yapısı olarak kullanan İskoç milliyetçiliği aynı zamanda devletaltı milliyetçi hareketlerin $A B$ içinde siyasal bağımsızlık edinmelerinin olanaklı olup olmadığı konusunu da gündeme getirmiştir. Dolayısıyla, etkinlik içinde bulunduğu bağlam, dönüştürmeye çalıştığı yapılar ve rekabet halinde bulunduğu aktörlerle dinamik etkileşimi çerçevesinde İskoç milliyetçiliğini incelemek, bu hareketin BK'nin siyasal yapısındaki dönüşüme etkisini ve Birliğin geleceği ile ilgili süregiden tartışmalardaki yerini ve rolünü anlamaya yardımcı olabilir. Dahası, SNP önderliğindeki İskoç milliyetçiliğini incelemek, genel anlamda $\mathrm{AB}$ ile devlet-altı milliyetçilikler arasındaki ilişkiyi anlama çabalarına da hizmet edebilir. Ayrıca, İskoç milliyetçiliği ve etkileri üzerine Türkçedeki kaynakların son derece sınırlı olduğu düşünülecek olursa ${ }^{2}$, bu araştırma ilgili literatüre bir katkı çabası olarak da görülebilir.

$\mathrm{Bu}$ çalışmada, İskoç milliyetçiliğinin incelemesinde SNP temel alınmıştır. Bunun nedeni, örgütlülük düzeyi, mobilizasyon yeteneği, seçmen desteği ve seçim başarılarını göz önüne aldığımızda, SNP'nin İskoç milliyetçiliğinin siyasal alandaki başlıca temsilcisi olmasıdır. Bu çerçevede, SNP'nin parti programları, manifestoları, liderlerinin demeçleri, hükümet programları ve 2014 bağımsızlık referandumu kampanyası analiz edilmiştir.

Milliyetçiliği her şeyden önce bir siyaset yapma şekli olarak gören bu çalışma, yukarıdaki soru ve sorunlara fırsat yapıları temelli bir cevap arayışına girişmektedir. İskoç milliyetçiliğinin bugününü ve ilgili güncel tartışmaları analiz etmek için tarihsel arka plan verilmekte, SNP’nin kimlik ve siyaset boyutunda temel özellikleri incelenmekte, ardından bağımsızlık referandumu sürecine yoğunlaşılmaktadır. Son olarak, AB referandumu sürecini ve sonuçlarını da dikkate alarak, İskoç milliyetçiliğinin BK’nin geleceği üzerindeki olası etkileri incelenmektedir. Böylelikle, bir devlet-altı milliyetçilik örneği incelemesi üzerinden milliyetçiliğin ve ulus-devlet temelli egemenlik anlayışının Avrupa bütünleşme sürecinde hala neden ve nasıl önemli kalabildiği sorgulanmaktadır.

1 Aynı siyasal olguyu adlandırmak için azınlık milliyetçiliği, etnik milliyetçilik, ayrılıkçı milliyetçilik, bölgesel milliyetçilik, mikro milliyetçilik, yeni milliyetçilik gibi farklı terimler olsa da bu çalışmada devlet-altı milliyetçilik terimi benimsenmiştir. Temel hareket noktası olarak söz konusu milliyetçi hareketlerin kendisini alan bu terim, diğerlerine kıyasla daha analitik ve kapsayıcı özelliklere sahiptir. Diğer terimlerin sorunlu yönlerine ilişkin bkz. İbrahim Saylan, Sub-state Nationalism within European Integration Process: A Comparative Study of Scottish, Basque and Kurdish Cases, Yayınlanmamış Doktora Tezi, Ankara, Bilkent Üniversitesi, Ekonomi ve Sosyal Bilimler Enstitüsü, 2011, s.24-27. Ayrıca bkz. Walker Connor, Ethnonationalism - A Quest for Understanding, Princeton NJ, Princeton UP, 1994.

2 Sınırlı sayıdaki Türkçe kaynak arasında örneğin bkz. Elçin Aktoprak, Devletler ve Ulusları, Tan Kitabevi Yayınları, Ankara, 2010 . 


\section{Bir Siyaset Yapma Şekli Olarak Milliyetçilik ve Fırsat Yapıları}

Milliyetçilik literatüründe önemli bir yer tutan modernist yaklaşımlardan biri olan siyasal yaklaşım, milliyetçilik olgusunu modern çağı tanımlayan radikal değişimler çerçevesinde yeniden şekillenen siyaset kurumuna odaklanarak açıklar. ${ }^{3} \mathrm{Bu}$ yaklaşımın temsilcilerinden Breuilly ${ }^{4}$, milliyetçiliğin ideolojik ve psikolojik yönleri olduğunu kabul etmekle beraber, söz konusu olguyu modern toplumun gelişim sürecinde iktidarın doğasında meydana gelen büyük dönüşümler çerçevesinde açıklamak gerektiğini savunur. Siyasetin iktidar peşinde koşmak olduğu, milliyetçiliğin de her şeyden önce siyasetle ilgili olduğu ön kabullerinden yola çıkan Breuilly, dönüşen koşullarda iktidar mücadelesi veren elitlerin, milliyetçiliği yeni dönemde modern devlet ile sivil toplum arasında ortaya çıkan boşluğu gidermeye ve aralarındaki güç mücadelelerinde kitlesel destek sağlamaya yönelik bir araç olarak geliştirip, kullandıklarını öne sürer. İktidarın odağı olması sebebiyle modern devlete yoğunlaşan Breuilly'in yaklaşımı, devlet-altı milliyetçilikleri incelerken, fırsat yapılarının oluşumu ve gelişiminde aktör odaklı iradi etmenlerin analize katılması kadar, devlete yapısal bir öğe olarak özel bir önem atfetmeyi de olanaklı kıldığından bu çalışmanın kuramsal eksenini oluşturmaktadır.

Milliyetçilik tiplerinden biri olarak devlet-altı milliyetçilik, diğer milliyetçilik tipleri ile milliyetçi ideolojinin temel savlarında buluşur. Öte yandan, bazı ayırt edici öğeler temelinde özgül bir milliyetçilik tipini oluşturur. Buna göre, devlet-altı milliyetçilik, farklı bir etnik \kültürel kimlik ve ortak geçmiş iddiaları temelinde, vatan olarak kabul edilen toprak parçası üzerinde kendi kendini yönetme hakkı talebiyle hareket eden siyasal hareket ve partileri ifade eden geniş bir kategoridir. Burada nihai amaç kültürel haklar edinmekten, bağımsız bir devlet kurmaya kadar farklılıklar gösterebilir. ${ }^{5}$

Devlet-altı milliyetçiler kendilerinden daha büyük ve güçlü bir etnik grup devlet gücünü tekelinde tutarken, millet olarak gördükleri kendi etnik gruplarının mevcut siyasal yapı içinde temsil edilmediğini ya da hiç yer bulamadığını düşünürler. Bu durumu değiştirmek amacıyla, toplumsal hareketler ve siyasal partiler olarak örgütlenirler; İrlanda ve Bask milliyetçiliklerinde görüldüğü gibi, bazı örneklerde şiddeti de içerecek şekilde bir dizi siyasal strateji yoluyla hedeflerine ulaşmaya çalışırlar. Devlet-altı milliyetçilikler, içinde bulundukları devlet yapısına ve hâkim milli kimlik tanımına meydan okuduklarından muhalif karaktere sahip bir milliyetçilik tipini oluştururlar. Genel anlamıyla, Breuilly’i takip ederek, milliyetçiliğin modern zamanlarda devlette yoğunlaşmış olan iktidarı korumaya ya da ele geçirmeye çalışan bir siyaset yapma şekli olduğunu düşünecek olursak, devlet-altı milliyetçiliği de kavramak için kimlik ve çıkar çatışmaları eksenlerine bakmak gerekir. Çünkü belli bir etnik kimliğin siyasallaştırılmasına dayanan devlet-altı milliyetçilik, genellikle ulus devletlerin merkezileştirme ve homojenleştirme girişimlerine karşı oluşan tepkiden ve/veya etnik farkındalığın oluşmasına yol açan modernleşmenin çatışmalı sonuçları gibi bir dizi değişen koşula bir cevap olarak ortaya çıkar.

Devlet-altı milliyetçiliğin ortaya çıkışında ve gelişiminde, etnik kimliğin siyasallaştırılması ve kitlelerin seferber edilmesi açısından elitlerin rolü önemlidir. Ancak, bunun kadar, kurumların, özellikle de devletin etkisi göz ardı edilemez. Bu nedenle, meselenin doğası ve dinamiklerini anlamak için fırsat yapılarına odaklanan bir siyasal yaklaşım gereklidir. Her bir devlet-altı milliyetçilik örneğinin,

3 Milliyetçilik literatüründeki başlıca yaklaşımlar hakkında ayrıntılı bir inceleme için bkz. Umut Özkırımlı, Milliyetçilik Kuramları - Eleştirel Bir Bakış, DoğuBatı Yayınevi, Ankara, 2008.

4 John Breuilly, Nationalism and the State (2.Baskı), Manchester, Manchester University Press, 1993. Siyasal yaklaşımın bir diğer önemli ismi ise, milliyetçiliği kitle siyasetinin yükselişi ve bunun mevcut siyasal sistem üzerindeki etkileri üzerinden açıklayan Hobsbawm'dır. Bkz. Eric J. Hobsbawm, Milletler ve Milliyetçilik (3.Basım), Ayrıntı Yayınları, İstanbul, 2006.

5 Helen Catt ve Michael Murphy, Sub-state Nationalism: A Comparative Analysis of Institutional Design, Oxford \& New York, Routledge, 2002, s.18. 
onun sadece ortaya çıkış şeklini etkileyen değil, aynı zamanda fırsat yapılarını şekillendiren özgül bir bağlamda ortaya çıkmış olduğunu düşünecek olursak, firsat yapılarının analizi aynı zamanda kitlelerin seferber edilmesi ve milliyetçi söylemin oluşturulması süreçlerine de ışık tutar.

Firsat yapıları modeli (opportunity structures model), toplumsal hareketleri inceleyen araştırmalarda sıklıkla kullanılan bir modeldir. Ancak genellikle sadece muhalif kolektif aktörleri sınırlayan ya da onlara güç veren dışsal faktörlere yoğunlaşır. ${ }^{6}$ Bu çalışmada firsat yapıları, devletaltı milliyetçiliğin içinde doğduğu, geliştiği içsel ve dışsal kaynak ve engelleri içerecek şekilde daha geniş bir siyasal çerçeveye karşılık gelmektedir.7 Geniş kapsamlı bu analitik çerçeve siyasal-kurumsal öğelerle sınırlı kalmaz, ekonomik, sosyal ve normatif yönleri de içerir.

Buradan hareketle, aşağıdaki analize temel teşkil ettiği şekilde iç içe geçmiş, etkileşim halindeki iki boyuttan söz edebiliriz. Devlet altı milliyetçi hareket ve partileri incelerken, içsel boyutu oluşturan temel faktörler şunlardır: Etnik kimliğin gücü, siyasal program, örgütsel kapasite, liderlik, parti içi hiziplerin varlığı, finansal ve beşeri kaynaklar, sosyal hareketler ve oy verenlerle bağlantılar ve medyada yer alma. Dışsal boyut, ulusal (devlet) ve uluslararası (devlet-dışı) etmenlerin bileşimidir ki bunlara çevresel etmenler de denir. Fırsat yapısında en önemli ulusal etmen; anayasası, parti sistemi, seçim sistemi itibariyle siyasal sistemdir. Uluslararası etmenler arasında ise uluslararası sistem, uluslararası örgütlerin ve $\mathrm{AB}$ gibi ulusüstü özelliklere sahip uluslararası oluşumların gelişimi, diğer ülkelerdeki devlet-altı milliyetçi hareketlerin yarattığı gösteri etkisidir. ${ }^{8}$

$\mathrm{Bu}$ noktada, Avrupa bütünleşme sürecine ilişkin bir parantez açmak yararlı olacaktır. Avrupa bütünleşme kuramları, büyük oranda yeni işlevselcilik ve hükümetlerarasıcılık yaklaşımlarının etkisi altındadır. İlk yaklaşım, bütünleşmenin AB’yi ulusüstü bir yapılanmaya doğru götürdüğünü, ikincisi ise bütünleşmeyi tercihleri ve göreli güçleri temelinde pazarlık yoluyla güvenilir kurumlar yaratan devletlerin temel aktörler olmaya devam ettikleri bir siyasal rejim olarak görür. ${ }^{9} \mathrm{Bu}$ çalışma, ulusüstücühükümetlerarasıcı zıtlığına yönelik olarak daha dengeli bir yaklaşımı benimser. Buna göre, farklı siyaset alanlarında farklı bütünleşme şekillerinin görüldüğü Avrupa bütünleşmesini "ulusüstü’den daha azı, hükümetlerarası'ndan daha fazlası" olarak nitelemek yerinde olacaktır. ${ }^{10}$

Son olarak, devlet-altı milliyetçiliği incelerken, içsel ve dışsal etmenlerin yanı sıra kritik olay ve gelişmelerin de önemi unutulmamalıdır. Teşvik edici ya da kışkırtıcı (eruptive/fomenting factors) olarak

6 Doug McAdam et.al., "Introduction: Opportunities, Mobilizing Structures, and Framing Processes-toward a Synthetic, Comparative Perspective on Social Movements", Doug McAdam et.al. (der), Comparative Perspectives on Social Movements, Cambridge, Cambridge University Press, 1996, s.1-20.

7 Milliyetçi hareketler ve firsat yapıları üzerine söz konusu teorik/metodolojik yaklaşımın ayrıntılı bir örneği için bkz. Liesbet Hooghe,"Nationalist Movements and Social Factors: A Theoretical Perspective", John W. Coakley (der.), The Social Origins of Nationalist Movements: The Contemporary West European Experience, London, Sage, 1992, s.21-44.

8 Lieven De Winter, “A Comparative Analysis of Electoral, Office and Policy Success of Ethnoregionalist Parties", Lieven De Winter ve Huri Türsan (der.) Regionalist Parties in Western Europe, London\&NY, Routledge, 1998, s.222-35; Pieter van Houten, Regional Assertiveness in Western Europe-A Statistical Exploration”, April 2001, Grenoble, s.16, https:// ecpr.eu/Filestore/PaperProposal/11d561d0-664a-4973-a424-91ce46fce5de.pdf, (Erişim Tarihi 15 Ekim 2015).

9 Avrupa bütünleşme kuramları üzerine bkz. Ben Rosamond, Theories of European Integration, Hampshire \& NY, Palgrave, 2000. İlk yaklaşıma örnek olarak bkz. Alec Stone Sweet ve Wayne Sandholtz, "European Integration and Supranational Governance”, Journal of European Public Policy, Cilt 4, No.3, Eylül 1997, s.297-317. İkinci yaklaşım için bkz. Andrew Moravcsik ve Frank Schimmelfennig, "Liberal Intergovernmentalism", Antje Wiener ve Thomas Diez (der.), European Integration Theory, Oxford, Oxford UP, 2009, s.67-90.

10 Ohrgaard, Jakob C. "Less Than Supranational, More Than Intergovernmental: European Political Cooperation and the Dynamics of Intergovernmental Integration”, Millennium - Journal of International Studies, Cilt 26, No.1, s.1-29. Ayrica bkz. Ann P. Branch ve Jakob C. Ohrgaard, "Trapped in the Supranational-intergovernmental Dichotomy: A Response to Stone Sweet \& Sandholtz", Journal of European Public Policy, Cilt 6, No.1, s.123-43. 
tanımlanabilecek bu etmenler, kitle desteğinin kazanılmasına yardımcı olabilir. Ekonomik, siyasal ya da ideolojik kaynak görevi gören bu etmenler olumlu ya da olumsuz nitelikte olabilirler. Kısacası, firsat yapıları modeli özellikle iki nedenle önemlidir: Siyasal, ekonomik, normatif boyutları içeren kapsamlı bir modeldir. Üstelik çoklu yapıda ve dinamik süreçte, devletin fırsat yapılarını şekillendirmede hala ne denli etkin olduğunu anlamaya yardımcı olur. İkinci olarak, bütünleşme süreçlerinin, güncel küresel gelişmelerin etkisini dikkate alarak, uluslararası boyutu da analize dâhil eder. Şimdi, bu çerçevede, fırsat yapılarına yoğunlaşarak İskoç milliyetçiliğinin yükselişini ve bunun farklı düzeylerdeki etkilerini ele alalım.

\section{İskoç Milliyetçiliğinin Başat Aktörü Olarak SNP}

“Dört ulusun birliği”ne dayanan, bir 'birlik devleti’ olarak kurulan BK devletinin kendine özgü gelişme yolu, milli birlik ve kimlik anlayışını Kıta Avrupası'ndaki başlıca örneklerden belirgin şekilde farklılaştırmıştır. İskoçya’nın İngiltere ile birleşmesi 1707'de "Birlik Anlaşması” yoluyla bir “mantık evliliği” şeklinde gerçekleşmiştir. İskoçya bağımsızlığından vazgeçse de karşllı̆ında İngiltere ile serbest ticaret ve büyümekte olan imparatorluğun nimetlerinden yararlanma hakkı elde etmiştir. İngiltere ise Protestan hanedanlığın devamını ve Fransa'dan gelecek saldırılara karşı sınırlarını güvence altına almıştır. ${ }^{11}$ Britanya devleti tarafından asimilasyona zorlanmayan İskoçlar, İngiltere'ye ve İmparatorluğun diğer bölgelerine göçle beraber yoğun bir kültürleşme (acculturation) sürecini yaşarken, İskoçya'da da İngilizce'nin hâkim olmasıyla birlikte dil İskoç kimliğinin ayırt edici unsuru olmaktan çıkmıştır. İmparatorluğun sunduğu avantajlar Britanyalı kimliğinin benimsenmesini kolaylaştırırken, sınıf siyaseti ve refah devletinin eşitlikçi sosyal politikalarının etkisi altındaki alt ulusal kimlikler de siyaseten önemsizleşmiştir. Bu süreçte, öte yandan, "Kutsal Üçleme” (Holy Trinity) denilen İskoç eğitim ve hukuk sistemleri ile ulusal İskoç Kilisesi’nin (Kirk) birleşme sırasında güvence altına alınması ve yerel yönetimlerin devamının sağlanması sayesinde İskoç kimliğinin özellikle İskoçya'da varlığını koruması da mümkün olabilmiştir. ${ }^{12}$ Kısacası, İskoçya bağlamında Britanya çatısı altında bütünleşme ile farklılı̆ğ sürdürme süreçleri birlikte var olmuştur.

Ancak, BK’nin 19 yüzyıl ortalarında başlattığı merkezileşme politikalarının yarattığı rahatsızlık Birliğin sorgulanmaya başlamasına neden olmuştur. İskoç elitlerinin ilk tepkisi, Londra'ya karşı Özerk Yönetim (Home Rule) hareketinin önderliğini yapan Liberal Parti’yi desteklemek olmuştur. İki dünya savaşı arasında dönemde ise ulusal düzeyde örgütlenmeye başlamışlardır. SNP bu süreçte, iki milliyetçi partinin birleşmesi sonucu 1934'te kurulmuştur. SNP 1970’lere kadar seçim başarısı gösterememiş, 1980’lerdeki düşüşünün ardından 1990'larla birlikte yükselişe geçmiştir.

SNP’nin yükselişi, öncelikle BK'den duyulan memnuniyetsizliğin bir sonucu olarak İskoçya ve İskoç kimliğinin güncel bir anlam kazanması ve partinin kendini İskoç seçmenlerin gözünde gerçekçi bir alternatife dönüştürmesi sayesinde olmuştur. İskoçya’nın güncel bir anlam kazanması iki temel yapısal nedenden kaynaklanmıştır. Bunlardan ilki, Britanya İmparatorluğunun dağılması sonucu Londra’nın cazibe merkezi olma özelliğini yitirmesidir. ${ }^{13}$ İkincisi, İskoçya’nın kömür ve çelik endüstrilerinde 1960'lar ve 1970’ler boyunca yaşadığı dramatik gerilemedir. Thatcher dönemindeki

11 Christopher Harvie, Scotland- A Short History, Oxford, Oxford University Press, 2014, s.114-142.

12 Tony Dickson, “Scotland is Different, OK?", David McCrone et.al. (der.), The Making of Scotland: Nation, Culture and Social Change, Great Britain, Edinburgh University Press, 1989, s.59.

13 Anthony, Birch, "Minority Nationalist Movements and Theories of Political Integration", World Politics, Cilt 30, No.3, 1978, s.325-344. 
ekonomik yeniden yapılanma ve deregülasyonun yol açtığı sanayilesizleşme İskoçya ekonomisine darbe vururken, güç kazanan hizmet sektörü sadece bazı bölgelere yarar sağlayabilmiştir. Muhafazakâr Parti'nin "kelle vergisi” olarak da bilinen Toplum Vergisi (Community Charge) için İskoçya'yı pilot bölge seçmesi huzursuzluğu daha da artırmıştır. Bu politika, sosyal refah devletinin eşitlikçi anlayışına darbe vurmakla kalmamış, aynı zamanda İskoç kimliğinin yükselmesini de körüklemiştir. Tüm bu gelişmeler İskoçya'da hayal kırıklığının, öfkenin artmasına yol açarken, 1970’lerin başında Kuzey Denizi'nde petrol bulunması, İskoçlar arasında "kendi başımıza da yapabiliriz" düşüncesini yaygınlaştırmıştır. Ancak, İskoçya'da Birliğe karşı tavrın değişmesinin tek nedeni ekonomik sorunlar sonucu oluşan göreli yoksullaşma değildir. İskoçya'da kişi başına düşen gelir Britanya ortalamasının altında olmamıştır. ${ }^{14}$ Asıl etmen siyasal farklılığın artışıdır. Bu süreçte, Thatcher'ın temsil ettiği Toryciliğe karşı yükselen tepkinin yanı sıra, İşçi Partisi’nin İskoçya’nın çıkarlarını korumada etkisiz kaldığı yönündeki algı da etkilidir. Kuzey İlanda’da IRA milliyetçiliğinin etnik-dilsel talepleriyle birlikte yükselen Gal milliyetçiliği, “dört ulus’un birliği”nin sonunun geldiği yönündeki iddiaların gündeme gelmesine neden olmuştur. ${ }^{15}$

Bu süreçte, SNP’nin savunduğu “ulusal bağımsızlık” politikası yoluyla İskoç kurumları üzerinde tam denetim fikri daha cazip bir hale gelirken ${ }^{16}$, partinin köklü bir örgütsel ve ideolojik dönüşüm geçirdiği görülür. 1940'larda kesin olarak bağımsızlık yanlısı bir partiye dönüşen SNP'de, 1979 yetki devri referandumu ${ }^{17}$ sonrası parti içi ideolojik bir çatışma yaşanmıştır. Bunun sonucunda, sadece bağımsızlık hedefine yoğunlaşılmasını savunan gelenekçilere karşı, ortanın-solu anlayışını destekleyen görüşler çoğunluk kazanmış ve SNP 1980'lerden itibaren bağımsızlıkçı bir sosyal-demokrat partiye dönüşmüştür. ${ }^{18} \mathrm{Bu}$ süreçte, toprak ve sınıf temelli ${ }^{19}$ siyasaların özgün bir bileşimine erişen SNP, kurumsal miras sayesinde varlığını güçlü şekilde devam ettirebilmiş, İskoç kimliğini siyasallaştırarak, ama kültürü değil, devleti başlangıç noktası olarak alarak, maddi çıkarlar odaklı bir siyaset yapmaya girişmiştir. ${ }^{20}$ SNP İskoç milliyetçiliğini, "iflas etmiş Birlik’e karşı, İskoç milletinin bir modernleşme projesi” olarak ilan etmiştir. ${ }^{21}$ Buna göre, millet sadece dayanışma sağlayan geniş bir aile olarak değil, merkezden ayrılırsa büyüyecek, zenginleşecek adeta büyük bir şirket gibi “hayal edilmiştir”. Bağımsız İskoçya'da pastanın büyütülüp, adilce paylaşılacağını vaat eden ${ }^{22}$ SNP'nin programında çevre duyarlılı̆̆ı, anti-nükleer duruş²3 gibi post-endüstriyel siyaset öğelerine de yer verilmektedir.

14 Michale Keating, Nations Against the State: the New Politics of Nationalism in Quebec, Catalonia, and Scotland, London, Macmillan, 1996, s.176.

15 Tom Nairn, The Break-up of Britain: Crisis and Neo-Nationalism (3.Bastm), Australia, Common Ground, 2003, s.1-80.

16 Peter Lynch, The History of the Scottish National Party, Wales, Welsh Academic Press, 2002, s.3.

171978 yılında çıkarılan İskoçya Yasası uyarınca İskoç Parlamentosu'nun kurulması için 1979'da İskoçya'da referandum yapıldı. Toplam seçmen sayısının \%40’ının desteğini alamazsa kadük olacağı ilan edilen söz konusu yasaya \%64 katılımın olduğu referandumda, katılımcıların \%51,6’sı destek verdi. Bu ise toplam seçmenin \%32,9'una karşılık geliyordu. Bu sonuca göre, İskoç Parlamentosu'nun kuruluşu rafa kaldırılmı̧ oldu. Peter Lynch, The History of the Scottish National Party, s.152.

18 Ibid., s.3.

19 SNP oylarının çoğunu alt ve orta sınıflardan alırken, üst sınıf İskoçlar Britanya Muhafazakârlı̆̆ını desteklemişlerdir. Ayrıntılı bilgi için bkz. Keating, Nations against the State.

20 Marcus Hoppe, "Sub-state Nationalism and European Integration: Constructing Identity in the Multilevel Political Space of Europe”, Journal of Contemporary European Research, Cilt 1, No 2, 2005, s.13-28.

21 SNP 1997 Genel Seçim Bildirgesi, s.4, http://www.politicsresources.net/area/uk/ge97/man/snp97.pdf (Erişim Tarihi 15 Aralık 2015).

22 SNP 2011 İskoçya Seçimleri Seçim Bildirgesi, s.3, http://votesnp.com/campaigns/SNP_Manifesto_2011_lowRes. pdf, (Erişim Tarihi 15 Aralık 2015).

23 SNP İskoçya BK'nin bir parçası kaldığı sürece BK’nin Trident nükleer silah programının sonlandırılmasını, İskoçya'nın bağımsız olması durumunda ise BK'nin söz konusu program çerçevesinde İskoçya açıklarında konuşlandırdığı her türlü 
Kısacası, fırsat yapıları çerçevesinden baktığımızda SNP’nin ulusal kimlik inşası yönünden önemli avantajları olduğunu, yeniden yapılanma sonucu siyasal parti karakterinin daha da güç kazandığını, Kuzey Denizi’nde petrol bulunmasının İskoç milliyetçiliğini güçlendirici bir etki yaptığını tespit edebiliriz. Hâlihazırda, bir devlet-altı milliyetçi parti için hayli elverişli koşullara sahip SNP'nin yelkenini rüzgârla dolduran ve bugün itibariyle onu sadece İskoçya'da değil, Britanya siyasal yapısı içinde de göz ardı edilemez bir aktöre dönüştüren ise BK'nin AT’ye üye olması ve 1997 Yetki Devri Referandumu sonrası İskoç Parlamentosu’nun kurulması olmuştur.

\section{Değişen Fırsat Yapıları ve SNP}

\section{BK'nin AT Üyesi OIması}

Geleneksel olarak Avrupa bütünleşmesi hakkında şüpheci bir tavra sahip olan BK, 1973'te AT'ye üye oldu. 1975'te üyeliğin devam edip etmemesi konusunda halk oylaması yapıldı. Halkın \%67,2'si devam etmesinden yana oy kullandı. SNP Ortak Pazar'ın İskoçya'nın çevresel konumunu pekiştireceğini düşündügünden, AT'yi seçkinci, bürokratik bir örgüt ve ulusal egemenlik ile kültürel kimliğe tehdit olarak gördüğü için oylamada "hayır" kanadında yer aldı. ${ }^{24}$ Ancak, İskoçya'da \%58,4 AT'ye evet çıkınca, İskoçların çoğunun AT yanlısı olduğunu görmüş oldu.

SNP'nin Avrupa bütünleşmesi konusundaki tutumu 1980'lerde bir dizi içsel etmen ve bütünleşmenin sosyal ve bölgesel boyutlarının derinleşmesi ile beraber değişmiştir. 1979 yetki devri referandumunun başarısız olması İskoç milliyetçiliğini krize sokmuştur. Thatcher'ın neoliberal politikaları ve Avrupa bütünleşmesinin sosyal ve siyasal boyutlarına direnç göstermesi İskoç cephesinde tepki yaratırken, İskoç milliyetçilerinin gözünde AT, özellikle ortak tarım ve bölgesel politikaları nedeniyle bölgesel çıkarların ve sosyal hakların koruyucusu haline gelmiştir. Böylece, AT, merkezileşme yanlısı, sağ kanat BK hükümetini aşmak için bir araç, Londra'ya karşı İskoç özyönetimi için dışsal bir destek sistemi olarak görülmeye başlanmıştır. ${ }^{25}$ Dahası, İskoçların çoğunun gözünde, AT, Thatcher'ın serbest Pazar ideolojisine bir alternatif, Muhafazakârların sonunu getirmeye çalıştığı sosyal demokrat projeyi gerçekleştirmek için yeni bir alana dönüştü. ${ }^{26}$ Böylece, önce sendikalar, sonra İşçi Partisi, ardından SNP, AT’den yana tavır aldılar. Bu süreçte, SNP Avrupa bütünleşmesini sonul amacına uygun olarak yararlanabileceği yeni bir fırsat yapısı olarak görmeye başladı ve 1988'de bağımsızlık hedefini "Avrupa içinde bağımsızlık" (Independence in Europe) olarak revize etti. ${ }^{27} \mathrm{Bu}$ değişim parti içinde ulusüstü gelişmeleri olumlayan, milliyetçiliği modernleşme olarak görenlerin zaferinin ilanıyd. ${ }^{28}$

SNP’nin "Avrupa içinde bağımsızlık” politikası bir dizi pragmatik gerekçeye dayanıyordu. Öncelikle, $A B$ üyeliğini devam ettirip, uluslararası toplumdan izolasyondan kurtulmak, böylece ayrılmanın siyasal maliyetini azaltmak amaçlanmıştı. İkinci olarak, bu politika $\mathrm{AB}$ pazarlarına girişi

nükleer unsuru taşımasını talep etmektedir. SNP 2011 İskoçya Seçimleri Seçim Bildirgesi, s.21, http://votesnp.com/ campaigns/SNP_Manifesto_2011_lowRes.pdf (Erişim Tarihi 15 Aralık 2015). Ayrıca bkz. http://www.snpcnd.org/ index.php?subaction=showfull\&id=1443732206\&archive=\&start_from=\&ucat=\& (Erişim Tarihi 21 Aralık 2015).

24 Peter Lynch, Minority Nationalism and European Integration, Cardiff, University of Wales Press, 1996, s.35.

25 Keating, Nations against the States, s.185.

26 Alice Brown et.al. Politics and Society in Scotland, Basingstoke, Macmillan Press, 1998, s.231.

27 Atsuko İchijo, Scottish Nationalism and the Idea of Europe, Oxon \& New York, Routledge. 2004, s.49-50.

28 Isobel Lindsay, "The SNP and the Lure of Europe", Tom Gallagher (der.), Nationalism in the Nineties, Edinburgh, Polygon, 1991, s.87. 
garantileyerek ayrılmanın ekonomik maliyetini azaltacaktı. Son olarak, SNP' ye göre AB küçük devletleri hayatta tutuyor, hatta önemli kılıyordu. Kıbrıs ve Malta ekonomik olarak güçlü olmak için coğrafi büyüklüğün gerçekten önemli olmadığını gösteriyordu. Daha da önemlisi, en küçük devletler bile el değiştiren dönem başkanlığı yoluyla $A B^{\prime} y i$ temsil edebiliyordu. Bunu ise sadece devletlik statüsü sağlayabilirdi. ${ }^{29}$

Pratikte, bu yeni pozisyon partinin kendini ayrılıkçı imajdan kurtarmasını sağlarken, ona modern, gerçekçi ve ilerici bir duruş kazandırdı. Seçmenlerin gözünde bağımsızlık hedefini daha inanılır kıldı. ${ }^{30}$ Üstelik Avrupa bütünleşmesinden yana duruşu İskoç ulusal kimliğinin bir öğesi olarak yorumlayarak, geleneksel olarak Avrupa-şüpheci olan Britanya ana akım partilerinden kendini ayırt edici bir öğeye dönüştürdü. ${ }^{31}$ Son olarak, Partinin kendine güvenini artırırken, ona Britanya siyaseti içinde Avrupa kartını oynama olanağı sağladı.

SNP geleneksel egemenlik tanımının $\mathrm{AB}$ içinde artık geçerli olmadığının farkında olmakla beraber, federal bir Avrupa fikrine de karşı çıkmaktadır. SNP AB'nin ulusüstü bazı öğelere sahip, hükümetler arası bir oluşumdan fazlasına dönüşmesini istememektedir. $\mathrm{AB}$ üye devletlerin birliği temelinde, belli alanlarda ortak politikalara sahip, bütün kontrolü ulusüstü bir yapıya devretmeyen bir oluşum olarak varlığını sürdürmelidir. ${ }^{32} \mathrm{Bu}$ yönüyle, SNP'nin geleneksel bir milliyetçi partiden farkı yoktur. ${ }^{33}$ SNP değişen koşulların ve bütünleşme süreçlerinin egemenlik kavramı üzerindeki değişimin farkındadır; ancak, bir önceki SNP başkanı Salmond'ın ifade ettiği "karşılıklı bağımlı bir dünyada, bağımsızlık önemlidir” ${ }^{34}$ fikrini savunmaktadır. SNP ulus devletin sonunu arzu etmediği gibi, AB'nin oraya doğru evrildiğini de düşünmemektedir. Siyasal gücün hala ulus devletlerin kontrolünde olduğunu düşünen SNP, İskoçya’nın bağımsız bir devlet olarak AB'nin eşit bir üyesi olmayı talep etmektedir. ${ }^{35}$ Dolayısıyla, SNP'nin meydan okuması ulus-devlet temelli statükoya değil, AB bütünleşme sürecinin fırsat yapılarında yarattığı yeni olanakları lehine kullanarak BK'ye yönelmektedir.

Bu çerçevede, SNP’nin “Avrupa içinde bağımsızlık” politikasını, AB bütünleşme süreci etkisiyle ortaya çıkan yeni bir egemenlik anlayışının yansıması olarak değil, bağımsızlık hedefini riskli gören İskoç seçmenlerin desteğini kazanma amaçlı bir strateji olarak görmek gerekir. Seçim sonuçlarına bakıldığında, bunun işe yaradığı açıktır. Ayrıca, SNP’nin yükselişi İskoçya'daki diğer partileri de AB'yi gündemlerine almaya zorlamıştır. Bu anlamıyla, SNP İskoçya siyasetinin Avrupalılaşmasının itici gücü haline gelmiştir. ${ }^{36}$ En önemlisi, Avrupalılaşmış bağımsızlık siyaseti yetki devri reformunun yolunu açıp, İskoçya Parlamentosu'nun yeniden kurulması yolunda önemli bir etmen olmuştur. ${ }^{37}$

29 Scottish Government Report 2013, Scotland in the European Union, s.14-17, http://www.gov.scot/Resource/ 0043/00439166.pdf (Erişim Tarihi 9 Kasım 2015).

30 Lynch, The History of the Scottish National Party, s.187.

31 Hoppe, "Sub-state Nationalism and European Integration", s.13-28.

32 SNP, Scotland: A European Nation, Scotland, 1992, s.5.

33 James Mitchell, "Member State or Euro-Region? The SNP, Plaid Cymru, and Europe”, David Baker ve David Seawright (der.), Britain For and Against Europe, Oxford, Clarendon Press, 1998, s.128.

34 SNP lideri Alex Salmond ile söyleşi, 9 Nisan 2013, The Brookings Institution, http://www.brookings.edu/ /media/ events/2013/4/09\%20scotland/20130409_scotland_salmond_transcript.pdf (Erişim Tarihi 10 Kasım 2015).

35 SNP 2010 Genel Seçim Bildirgesi, s.19, http://www.politicsresources.net/area/uk/ge10/man/parties/SNP.pdf (Erişim Tarihi 10 Aralık 2015).

36 Mitchell, "Member State or Euro-Region?", s.121.

37 Paolo Dardanelli, Between the Two Unions- Europeanisation and Scottish Devolution. Manchester University Press, Manchester, 2002, s.140. 


\section{Yetki Devri Referandumu}

Merkezileşmenin yarattığı rahatsızlıklar, AB’nin bölge odaklı politikaları, Kuzey İlanda sorununu çözme yönünde oluşan siyasi irade, İskoçya ve Galler'de devlet-altı milliyetçi partilerin seçim başarıları BK'nin yetki devrine gitmesinin başlıca nedenleri olarak görülebilir. Referandum sürecine İşçi Partisi’nin “yetki-devri yoluyla birlik” stratejisi hız vermiş ve 1997 yılında yasama-öncesi referandum yapılmıştır. İskoç halkına iki soru sorulmuştur: İskoç Parlamentosu kurulmalı mı? Bu parlamento, vergilerde ayarlama yapma gücüne sahip olmalı mı? Katılım oranının \%60,2 olduğu referandumdan ilk soruya $\% 74,3$, ikinciye $\% 63,5$ "evet" sonucu çıkmıştır. ${ }^{38}$ Bunun üzerine Britanya Parlamentosu 1998'de İskoçya Parlamentosu ve Hükümeti’ni kuran İskoçya Yasası́nı çıarmıştır. Yasaya göre, İskoçya Parlamentosu (Holyrood) daha önce İskoçya Bakanlığı tarafından üstlenilmiş olan alanlarda (devolved matters) yasama yetkisi almıştır ki bunlar sağlık hizmetleri, yerel yönetim, eğitim, konut, ulaşım, polis, yargı, tarım, sanat ve sosyal hizmetleri kapsamaktadır. Parlamento ayrıca belirlenen gelir vergisi miktarlarında 3 sente kadar değişiklik yapma hakkı elde etmiştir. Anayasa, dış politika, savunma, ulusal güvenlik, merkezi ekonomik işler, sosyal güvenlik konuları, vatandaşlık ve göç Westminister'ın "saklı haklar” 1 (reserved matters) olarak kalmıştır.

Yasaya göre, İskoç Hükümeti başbakanı (ilk bakan-first minister) İskoçya Parlamentosu tarafından seçilir ve Kraliçe tarafından atanır. Parlamento 129 üyelidir. Karma üyeli nispi temsil sistemine göre vekillerin 73 tanesi tek turlu dar bölge sistemine göre, geriye kalan 56 üye ise sekiz bölgede liste usulü nispi temsil sistemine göre seçilmektedirler. BK’de uygulanan çoğunluk sisteminin aksine burada karma sisteme geçilmesi kurumsal bir yeniliktir. Böylece, gelecekte olası bir İskoç milliyetçisi partinin tek başına hâkimiyetinin engellenmesi amaçlanmıştır. Ancak aynı yenilik, İşçi Partisi’nin İskoçya'daki seçim hegemonyasının kırılmasının yolunu da açmıştır. ${ }^{39}$

Yetki devri ile BK, bütün siyasal sistem üzerinde önemli etkileri olan esaslı bir yönetsel ve siyasi yeniden yapılanma süreci yaşamıştır. BK İskoçya, K. İrlanda ve Galler'deki yetki devirleri sonrası "bölgeselleşmiş bir üniter devlet"e (a regionalized unitary state) dönüşmüştür. ${ }^{40}$ İskoç milliyetçileri açısından tarihi önemde olan İskoçya Parlamentosu'nun yeniden kurulması, fırsat yapıları üzerinde önemli değişiklikler yaratmıştır. Yeni yapıda ana akım partiler İskoç çıkarlarına daha duyarlı hale gelmek zorunda hissetmişlerdir. SNP seçim sisteminin nispi temsil yönünün avantajıyla Parlamento'da kendine güçlü bir yer edinebilmiştir. Bugün İskoçya'da iki partili sistem geçerliliğini kaybetmiştir. Hatta 1999'dan bu yana yapılan İskoçya seçimleri SNP’nin seçmen desteğini aşamalı olarak arttırdığını, 2015 Britanya seçimleri sonuçları ise SNP'nin rakip partileri dramatik bir şekilde zayıflattığını göstermektedir. Dolayısıyla, İskoçya Parlamentosu ve Hükümeti, İskoçya’nın özyönetim gücünün göstergesi olmakla kalmamış, merkeze baskı yapmada, onunla pazarlık yapmada kurumsal birer araç işlevi üstlenmişlerdir. Dahası, yeni fırsat yapıları AB kurumları ve ulusötesi aktörlerle doğrudan ve dolaylı ilişkiler kurabilme konusunda da yeni kaynaklar ve kanallar sağlamışlardır.

38 House of Commons Library, Richard Dewdney Social and General Statistics Section, Results of Devolution Referendums (1979ł1997), 10 Kasım 1997, s.12, file:///C:/Users/user/Downloads/RP97-113\%20(1).pdf (Erişim Tarihi 14 Temmuz 2016).

39 David Judge, Political Institutions in the United Kingdom, Oxford \& New York, Oxford University Press, 2005, s.183.

40 John Loughlin, "Introduction: The Transformation of the Democratic State in Western Europe", John Loughlin (der.), Subnational Democracy in the European Union, Oxford \& New York, Oxford University Press, 2001, s.14. 


\section{AB içinde SNP}

1998 İskoçya Yasası'na göre AB ile ilişkiler Londra'nın saklı hakları arasındadır. Ancak, İskoçya Parlamentosu'na devredilen yetki alanlarının pek çoğu AB'nin yetkili olduğu alanlarla çakışmaktadır. Ayrıca, Londra yetkisinde olan alanları etkileyen $\mathrm{AB}$ politikalarının elbette İskoçya üzerinde önemli etkileri olmaktadır. $\mathrm{Bu}$ yüzden, $\mathrm{AB}$ ile ilişkilerin yürütülmesi konusunda çatışmaları önlemek için karmaşık bir dizi kurumsal düzenleme yapılmıştır. ${ }^{41}$

SNP, İskoçya’nın millet statüsünü $A B$ içinde güçlendirmekiçin $A B$ 'nin sunduğu firsat yapısından sonuna kadar yararlanmak gerektiğini düşünmektedir. Bu yönde, Avrupa Ortak Pazarı’nın İskoç ekonomisinin daha dinamik, yenilikçi ve başarılı olması için hayati önemde olduğu vurgulanırken, AB'nin yaşam standartlarına ve bölgesel ekonomilere katkıda bulunan eşitlikçi yönünün de altı çizilmektedir. İskoç milliyetçisi olsun ya da olmasın İskoç siyasi aktörleri; Avrupa Parlamentosu, Ekonomik ve Sosyal Komite, Bölgeler Komitesi gibi pek çok AB kurumunda Avrupalılaşmış İskoç çıkarlarını temsil etmektedirler. Ayrıca, İskoç İşçi Partisi Hükümeti döneminde 2004'te İskoç Hükümeti, ilan ettiği AB stratejisine göre, "Avrupa'da İskoç çıkarlarını desteklemek, BK Hükümeti ile beraber $\mathrm{AB}$ konularında etkiyi arttırmak, Avrupa'da İskoçya’nın profilini güçlendirmek” amacıyla paradiplomatik ${ }^{42}$ etkinlikler başlatmıştır. Farklı ülkelerden bölgeler arası ekonomik temelli, bilgi ve tecrübe paylaşımı odaklı işbirliği anlaşmaları yapılmış, böylece İskoç ekonomik çıkarlarına hizmet etmenin yanı sıra İskoçya’nın görünürlügüunün arttırılması hedeflenmiştir.

SNP açısından bu kanallar İskoçya için maddi faydalarının ötesinde, bağımsızlık hedefine ulaşmada değerli birer araç olarak görülmektedir. Bunlar arasında, paradiplomatik etkinlikler özellikle önemlidir ki SNP Avrupa Parlamentosu seçimlerini 'Avrupa içinde bağımsızlık' hedefini güçlendirmek, $\mathrm{EFA}^{43}$ çatısı altındaki ittifakını ise "devletsiz bir halk" olan İskoçların bağımsızlık taleplerine destek sağlamak için kullanmaktadır. Ancak, yetki devri ile beraber uluslararası görünürlük ve etkinlik açısından firsat yapılarının İskoçya lehine güçlendiği görülse de Avrupa düzeyinde açılan kanalların kullanımına giriş koşulludur ve Merkez ile uyum aranmaktadır. Dolayısıyla, İskoçya milliyetçilerinin paradiplomatik faaliyetleri bir çatışma konusu olmaya devam etmektedir. SNP mevcut yapıları bir gün bağımsız olacak İskoçya'nın millet olarak profilini artırmak için kullanırken, BK ise Birlik'i koruma gayreti içindedir. Tansiyonu giderek yükselen bu çatışma, en sonunda Eylül 2014'te ülkeyi "birlik devleti”nin devamı konusunda zorlu bir siyasal teste girmeye zorlamıştır.

\section{İskoç Bağımsızlık Referandumu: Kampanyalar, Yankılar, Sonuçlar}

SNP’nin çoğunluğu sağlayıp, tek başına hükümet kurma hakkı elde ettiği 2011 İskoçya seçimleri İskoçya açısından bir dönüm noktası oluşturdu. Başlıca amacı İskoçya'nın bağımsızlığı olan SNP'nin iktidara gelmesi, BK’yi İskoçya’nın bağımsızlığı konusunda referanduma zorladı. Anayasa "saklı meseleler" içerisinde yer alsa da 2012'de BK ve İskoçya hükümetleri arasında varılan Edinburgh Anlaşması'na göre, referandum düzenleme konusunda İskoç parlamentosu geçici olarak yetkili kılındı. İskoç Parlamentosu 2013 tarihli İskoçya Bağımsızlık Referandumu Yasasını çıkardı. Kraliyet onayından sonra, 18 Eylül 2014 tarihinde referandum yapılması kesinleşti.

41 Judge, Political Institutions in the United Kingdom, s.188-9.

42 Devlet-altı ya da bölgesel aktörlerin kendi çıkarlarını savunmak ve ilerletmek için yürüttükleri uluslararası ilişkiler faaliyetleri paradiplomasi olarak adlandırılır.

43 European Free Alliance, Avrupa Parlamentosu'nda yer alan siyasal parti platformlarından biridir. EFA üyeleri yer aldıkları ulus devletler içinde bağımsızlık ya da özerklik peşinde koşan siyasal partileri barındırır. Ayrıntılı bilgi için bkz. http:// www.e-f-a.org/home/ (Erişim Tarihi 19 Aralık 2015). 
Bağımsızlık yanlıları ve karşıtları Yes Scotland ve Better Together kampanyaları olarak iki ana grupta örgütlendiler. ${ }^{44}$ Bunların yanı sıra, farklı isimlerle başka kampanyalar, siyasi partiler, gazeteler, tanınmış kişiler de Evet ya da Hayır lehine rol aldılar. Siyasal partiler düzeyinde; SNP, İskoç Yeşiller Partisi, İskoç Sosyalist Partisi Evet cephesinde yer alırken, Muhafazakâr Parti, İşçi Partisi, Liberal Demokrat Parti Hayır cephesini oluşturdular.

İşçi Partisi milletvekillerinden Alistair Darling'in başkanlığını yaptığı, İskoçya’nın BK'nin bir parçası olarak kalması gerektiğini savunan Better Together kampanyasının temel argümanlarından biri Birlik'in tarihsel anlam ve önemi oldu. Ülkenin tarihinin hep beraber yapıldığı, BK'yi özel yapan kurumların birlikte kurulduğu vurgulandı. Dört ulusun zaman içinde iç içe geçtiği ve mevcut "karşılıklı bağımlılığın" takdir edilmesi gereken bir bağ olduğu savunuldu. "Hayır" cephesinin tekrar tekrar işlediği diğer noktalar ekonomi, güvenlik, dış politika ve $A B$ üyeliği konuları oldu. Buna göre, Hayırcılar, BK’nin bir parçası olarak İskoç ekonomisinin güvende olduğunu, BK ekonomisinin ölçeği, gücü ve istikrarı nedeniyle İskoç ekonomisi için büyük avantajlar sunduğunu, İskoçya için en iyisi isteniyorsa, bunun mevcut bağların daha da güçlendirilmesinden geçtiğini vurguladılar. Hem güvenlik hem de dış politikada etkenlik açısından, BM Güvenlik Konseyi, NATO ve AB'nin bir parçası olan BK'nin İskoçlar için hala en iyisi olduğunu savundular. AB üyeliğine gelince, bağımsızlık durumunda, İskoçya'nın üyelik için yeni baştan başvuru yapması gerekeceğini iddia ettiler. Kısacası, İskoçya BK'nin bir parçası olarak kalmalıdır diyen Hayırcılar, Birlik’ in sağladığı kazanımları vurgularken, bağımsızlığın yerleşik düzeni bozup belirsizlik getireceğini, bunun da istikrarsızlı̆ga yol açacağı tezini işlediler.

İskoçya’nın bağımsızlığı için örgütlenen, Yes Scotland kampanyasının başat aktörü SNP’ydi. SNP hükümette olduğundan, referandum sürecinde bağımsızlık politikası konusunda liderlik yapan esas olarak İskoçya Hükümeti oldu. SNP'li üyelerden oluşan İskoçya Hükümeti 2013'te bağımsızlığa giden yolu ayrıntılı şekilde tarif eden Scotland's Future adlı bir White Paper yayınladı. Bunu referandumla bağımsızlığını elde edeceği varsayılan İskoç devletini yönetmede esas teşkil edecek geçici anayasa taslağı olan ve 2014'te yayınlanan The Scottish Independence Bill izledi.. ${ }^{45}$ SNP parti dokümanları ile uyum gösteren söz konusu belgeler her şeyden önce temel dayanak noktalarını şöyle tanımlamaktadırlar: İskoçya'da, İskoçya toprağında yaşayan ve çalışanlardan oluşan İskoç halkı egemendir. Halk egemenliği radikal, eşitlikçi ve demokratik bir ilkedir. Ayrıca, İskoçya’yı ilgilendiren kararlar İskoçya'da ve İskoç halkı tarafından alınırsa, bu İskoçya'nın yararına olacaktır. Çünkü bu sadece gerçek anlamda demokrasiyi değil, ekonomik performansı yükselterek daha zengin bir İskoçya’yı da mümkün kılacaktır. Dolayısıyla, bağımsızlık sadece normatif değil, pragmatik temelde de meşrulaştırılmaktadır. Aslında, İskoçya’nın bağımsızlığı tam bir kopuş anlamına gelmeyecektir. BK'den çıkılacak, ama Commonwealth'in üyesi olarak yola devam edilecektir. Dolayısıyla, Kraliçe parlamenter demokrasi ile yönetilecek bağımsız İskoçya'nın devlet başkanı olmayı sürdürecektir. Dahası, Euro bölgesine dâhil olmayı İskoçya'nın çıkarına görmediğinden, ulusal para birimi olarak sterlin kullanımının korunması savunulmaktadır. Daha da önemlisi, "Avrupa içinde bağımsızlık" hedefinin ifade ettiği gibi $A B$ ’ye üyeliğinin devam etmesine özel önem verilmektedir. Bu noktada, BK'den kopmak istenilmesine karşın, BK'ye tanınan bazı AB politikalarının dışında kalma tercihlerini (opt-outs) bağımsız İskoçya’nın da devralacağı savunulmaktadır. Bu çerçevede, Euro'ya dâhil olmamanın yanı sıra, Schengen'e üye olunmayacak, Common Travel Area uygulaması ile yola devam

44 Kampanya sunuşları ve Better Together'ın argümanlarının ayrıntılı dökümü için bkz. http://www.yesscotland.net/; http://b.3cdn.net/better/8e048b7c5f09e96602_jem6bc28d.pdf (Erişim Tarihi 8 Aralık 2015).

45 The Scottish Government, Scotland,s Future - Your Guide to an Independent Scotland, 2013, http://www.gov.scot/ resource/0043/00439021.pdf; The Scottish Government, The Scottish Independence Bill, 2014, http://www.gov.scot/ resource/0045/00452762.pdf (Erişim Tarihi 8 Aralık 2015). 
edilecektir. ${ }^{46}$ Aslan payını İskoçya’nın alacağı Kuzey Denizi’ndeki petrol ve gaz rezervlerinin barışçıl yolla bölüşülmesi, İskoçya’nın NATO üyeliğini korurken, İskoçya’nın nükleer silahlardan arındırılması, diğer bağımsızlık vaatleri olarak öne çıkmıştır.

Buna karşılık, bağımsızlık yanlılarının söylem ve vaatleri hem Better Together kampanyasının hem de BK Hükümeti’nin hedef tahtasında yer almıştır. BK Hükümeti raporlarında sterlinle yola devam etmek isteyen İskoçya'nın resmi para birliği için Londra ile yapmak isteyeceği anlaşmanın kabul görmeyebileceği, kabul görse de faiz oranları ve emisyon hacimleri konusunda Bank of England’a bağımlı kalacağı vurgulandı. ${ }^{47}$ Ayrıca, petrol rezervlerinin bölüşümü esnasında coğrafi kriterin mi yoksa nüfus kriterinin mi kullanılacağının belirlenmesi gerektiği, ayrıca rezervlerin hacmi konusunda rakamların abartılı olabileceği öne sürüldü. ${ }^{48}$ Nükleer karşıtı olan SNP’nin İskoçya'da konuşlu Trident' in taşınmasını istemesi ile üyesi olarak kalmaya devam etmek istediği NATO'nun nükleer caydırıcılık misyonuna ters düştüğu diğer bir eleştiri konusu oldu. ${ }^{49}$ SNP de buna karşı Danimarka ve Norveç'in NATO üyeleri olduğu ama nükleer güçleri olmadığ tezini ortaya sürdü. ${ }^{50}$ Kampanya sırasında belki de en tartışmalı konu $\mathrm{AB}$ üyeliği oldu.

$A B$ üyesi olan herhangi bir devletten daha önce ayrılma yaşanmadığı için $A B$ açısından da İskoçya’nın olası bağımsızlığı yeni bir durum ortaya çıkardı. İskoç Hükümeti bağımsızlık referandumu ile bağımsızlık ilanı arasında öngördüğü 18 aylık süre içinde $A B$ ile müzakere edip, üyeliğin sorunsuz şekilde devam ettirileceğini savundu. Ancak, kampanya boyunca bu konu netliğe kavuşmadı. İskoç Hükümeti Maastricht Antlaşması’nın yeni üye başvuruları için geçerli olan 49. maddenin değil, hâlihazırda 1973'ten beri AB'nin bir parçası olunduğu için 48. maddenin kullanılarak, Kurucu Antlaşma'da tadilat yoluyla konunun çözüme kavuşturulabileceğini savundu. Böylece, İskoçya, BK'nin bir parçası olarak sahip olduğu her türlü hak, yükümlülük ve ayrıcalığı yeni kurulacak devlete taşıyabilecekti. ${ }^{51}$ Bağımsızlık ilanını $\mathrm{AB}$ üyesi olarak yapacağını iddia eden Evetçilere karşı, Hayırcı cephe İskoçya bağımsız olursa yeniden başvuru yapmak zorunda kalacaktır tezini işledi. Aslında, bu mesele 48. maddeye göre ele alınacak olsa bile, tüm üyelerin olurunun alınması gerektiğinden müzakerelerinin başarıyla sonuçlanacağının bir garantisi yoktu. AB açısından bakıldığında, İskoçya’nın bağımsızlı̆̆ına soğuk bakıldığını söyleyebiliriz. Bu hem çok parçalı bir yapının arzu edilmemesi hem

46 BK ve İrlanda vatandaşlarının karşılıklı olarak minimum kontrolle ya da hiç kontrol olmaksızın iki ülke arasında seyahat edebilmesine olanak tanıyan, ikili anlaşma yoluyla oluşturulmuş ortak seyahat bölgesi.

47 BK Hükümeti Hazine Bakanlığı Raporu, “Scotland Analysis: Currency and Monetary Policy, Nisan 2013, s.69, https:// www.gov.uk/government/uploads/system/uploads/attachment_data/file/191786/ScotlandAnalysis_acc-1.pdf , (Erişim Tarihi 18 Mart 2016). Ayrıca, bağımsızlık referandumu kapsamında para birimi ve politikasına ilişkin beş farklı senaryonun özlü bir karşılaştırması için bkz. s.10.

48 İskoç Hükümeti'nin raporuna göre, 1,5 trilyon sterline kadar gelir getirmesi söz konusu olan rezervlerin yaklaşık \%90'1 İskoçya'ya aittir, bkz. The Scottish Government, Government Expenditure and Revenue Scotland, http://www.gov.scot/ Topics/Statistics/Browse/Economy/GERS ; Ayrıca bkz. "Scotland in numbers", BBC News, 25 Kasım 2013, http:// www.bbc.com/news/uk-scotland-24866266 (Erişim Tarihi 1 Aralık 2015). İskoç milliyetçilerinin tahminlerinin abartılı olduğuna dair yorumlara örnek olarak bkz. "SNP accused of..., The Guardian, 20 Ağustos 2014, http://www. theguardian.com/business/2014/aug/20/snp-accused-exaggerating-north-sea-oil-reserves (Erişim Tarihi 19 Mart 2016).

49 “Former NATO commander attacks SNP defence policy”, BBC News, 31 Ağustos 2014, http://www.bbc.com/news/ uk-scotland-scotland-politics-29005808 (Erişim Tarihi 18 Mart 2016).

50 25Ağustos2014tarihindeBBCOneScotland'dayayınlanan,ScotlandDecides:Salmondvs.Darlingbaşlıklıtartışmaprogramı TV kaydı için bkz. https://www.youtube.com/watch?v=33Z9l-rWgfA (Zaman Aralı̆̆ı:1:18,15-1:18,52/1:29,02) (Erişim Tarihi 18 Mart 2016).

51 İskoçya’nın $\mathrm{AB}$ üyeliği sorunun yanı sıra, İskoçya’nın olası bağımsızlı̆̆ı sonrası BK'nin geri kalan kısmının statüsünün ne olacağı konusunda yasal görüş için bkz. James Crawford ve Alan Boyle, "Annex A Opinion: Referendum on the Independence of Scotland, International Law Aspects, https://www.gov.uk/government/uploads/system/uploads/attachment_data/ file/79408/Annex_A.pdf (Erişim Tarihi 1 Aralık 2015). 
de BK'nin o vakit yapmayı konuştuğu, sonradan yapmaya kesin karar verdiği AB'de kalmaya devam edelim mi referandumu konusunda BK'nin üyesi olarak kalmaya devam edecek İskoçya'nın BK'nin $A B$ 'de kalma ihtimalini artıracak olmasıydı. Dolayısıyla, verilen birkaç demeci hariç tutarsak ${ }^{52}, \mathrm{AB}^{\prime}$ nin genel tutumu olanları uzaktan izleyip, tartışmaları ilgili ülkenin iç meselesi olarak görmek yönünde oldu. Öte yandan, SNP, İskoç Hükümeti bunu yapmaya yetkili olmadığından BKHükümeti’ni bağımsız İskoçya'nın $A B$ üyelik durumunun ne olacağına dair $A B$ ’nin resmi görüşünü almaya teşvik etse de Muhafazakâr Parti Hükümeti referandumundan önce bağımsızlık koşullarını müzakere etmeyeceğini bildirerek bunu kabul etmedi. ${ }^{53}$

Bağımsızlık referandumu sürecinde yapılan tartışmalar katılımcıları ve etkileri itibariyle BK ile sınırlı kalmadı. Süreç İskoçya’nın olası bağımsızlı̆̆ının yaratabileceği "gösteri etkisi”nden endişe eden başta İspanya olmak üzere bazı $\mathrm{AB}$ ülkeleri tarafından yakından takip edildi. Hatta İspanyol Hükümeti BK'deki tartışmalara doğrudan dâhil oldu. İskoçya örneği özellikle bağımsızlık referandumu hakkı elde etmesi sonrası Katalan milliyetçiliği açısından kuvvetli bir referansa dönüştü. Normatif düzlemde, Katalan milliyetçileri BK'nin İskoçların kendi kaderini tayin hakkına saygı gösterdiğini, İspanyol devletinden aynı yönde beklentileri olduğunu vurguladılar. Müttefik izlenimi vermek istemese de SNP yetkilileri, İspanya'nın Katalan halkına referandum hakkı vermemesinin, demokrasi ve Avrupalılık ile bağdaşmayacağını, hatta patlayıcı etkileri olacağını belirtti. ${ }^{54}$ SNP'nin Katalan milliyetçiliğine desteğini, devlet-altı milliyetçi hareketler arasındaki aktif dayanışmanın bir yansıması olmaktan çok, partinin İskoçya bağlamında devlet-altı milliyetçi söyleminin meşruiyetini artırma çabaları çerçevesinde kullandığı, araçsal bir unsur olarak yorumlamak gerekir. Yukarıda değinilen EFA örneğinin gösterdiği gibi, devlet-altı milliyetçilikler arasındaki işbirliğinin önünde ciddi engeller bulunmaktadır. Ancak, firsat yapıları modelinin bir öğesi olarak, "gösteri etkisi", hala büyük oranda mevcut ulus-devlet yapıları içerisinde şekillenen fırsat yapılarına uluslararası düzeyden destek sağladığı için değer kazanmaktadır. İlgili ulus-devletler açısından ise diğer devletlerden yayılan söz konusu etki, mevcut ulus-devletleri tehdit eden bir unsur olarak algılanmaktadır. Bu nedenle, İskoç milliyetçiliğinin geldiği noktadan İspanyol devletinin rahatsız olması şaşırtıcı görünmemektedir. SNP İskoç Parlamentosu'nda çoğunluk sağladıktan sonra referandum yolunu açmıştır. Aynı şekilde, 2015 seçimlerinde Katalan milliyetçileri Katalan Parlamentosu'nda çoğunluk sağladıktan sonra, açıkça bağımsızlık ve bunun için referandum talep etmektedirler. Üstelik $\mathrm{AB}$ üyesi bir devletin siyasal sisteminin parçası olarak, açıkça bağımsızlık hedefi peşinde koşan sadece SNP iken, 2015'te kurulan Junts pel Si (Evet İçin Birlik) koalisyonu da Katalonya'nın da aynı yola girme çabasında olduğunu göstermektedir. ${ }^{55}$ Buna karşı, İspanyol devleti özellikle Katalan milliyetçiliğini cesaretlendiren İskoç bağımsızlıkçı hareketinin amacına ulaşamamasının önemini vurgulamaktadır. İspanya başbakanı Rajoy İspanya ile BK farklı örnekler deyip ikisini birbirinden ayırsa da İspanya’nın İskoçya’nın bağımsızlığına olumsuz baktı̆̆ını açıkladı.

52 Örneğin, Avrupa Komisyonu başkanı Barroso'nun demeci için bkz. "Scottish independence: Barroso says joining EU would be 'difficult”, BBC News, 16 Şubat 2014, http://www.bbc.com/news/uk-scotland-scotland-politics-26215963 (Erişim Tarihi 9 Kasım 2015).

53 Scottish Government Report 2013, Scotland in the European Union, http://www.gov.scot/Resource/0043/00439166. pdf s.12 (Erişim Tarihi 9 Kasım 2015); Ayrıca bkz. "Unionists urged to sign EU letter", The Herald Scotland, 31 Ocak, 2013, http://www.heraldscotland.com/news/13090395.Unionists_urged_to_sign_EU_letter/ (Erişim Tarihi 9 Kasim 2015).

54 “SNP tells Madrid”, The Herald Scotland, 20 Eylül 2015, http://www.heraldscotland.com/news/13771674.SNP_tells_ Madrid_allow_Catalonia_an_independence_referendum/ (Erişim Tarihi 9 Kasım 2015).

55 Katalonya Parlamentosu resmi websitesi, http://catalanassembly.org/en/catalonia-said-yes-to-independence/ (Erişim Tarihi 12 Kasım 2015). 
AB'de parçalanma ve belirsizlik yaratacağı için $A B$ elitlerinin genel olarak ayrılıkçı hareketlere soğuk baktığını belirtti. Hatta İskoçya'nın bağımsızlığının AB’nin dağılmasına yol açabileceğini iddia etti. Bağımsız İskoçya’nın AB'ye üyeliği meselesi tartışmasına da katılan Rajoy, bağımsız İskoçya'nın SNP'nin savunduğu gibi 18 ay gibi kısa bir süre içinde $A B$ üyeliği şartlarını müzakere etmesinin mümkün olmadığını öne sürdü. ${ }^{56}$

Nihayet, $B K$ ve $A B$ sathında tanık olunan zorlu tartışmalar sonrası İskoç bağımsızlık referandumu 18 Eylül 2014'te gerçekleştirildi ve İskoç halkına şu soru soruldu: "İskoçya bağımsız bir ülke olmalı mıdır?" (Should Scotland be an independent country?). ${ }^{57} 4.283 .938$ toplam seçmenin $\% 84,6$ 'sı oy kulland. ${ }^{58}$ Evetçiler \%44,65'te kalırken, Hayır cephesi oyların \%55,25'ini aldı. "Evet" oyları 32 seçim bölgesinden sadece Glasgow, Dundee, North Lanarkshire, West Dunbartonshire'da fazla çıkarken, başkent Edinburgh ve diğer tüm bölgelerde Hayırcılar üstünlük sağladı. 16 yaş ve üzeri İskoçya'da yaşayan Commonwealth ve $\mathrm{AB}$ ülkesi vatandaşlarının da oy kullandığı bu referandumda, orta ve alt sınıflar arasında Evet eğiliminin görece daha kuvvetli olduğu, kadınların, 18-24 yaş arası gençlerin, yaşlıların, üst sınıfların ve İskoçya dışında doğmuş olanların çoğunun Hayır oyu verdiği ortaya görüldü. ${ }^{59}$

Referandumda bağımsızlık peşinde koşanlar istediklerini alamadılar, ancak BK Hükümeti kamuoyu yoklamalarında bağımsızlık yönünde halkın desteği ciddi şekilde yükselince referandum öncesi İskoçya'ya daha fazla yetki devri sözü vermek zorunda kaldı. Bu hamle İskoçya özelinde, İskoç milliyetçiliği etkisiyle BK'nin siyasal yapısının değişmeye devam edeceğini göstermektedir. Can alıcı soru, bu etkinin ne düzeyde kalacağıdır.

\section{İskoç Milliyetçiliği Gölgesinde BK'nin Geleceği ve Brexit}

Bağımsızlık referandumunu kaybeden SNP, Mayıs 2015'te yapılan BK genel seçimlerinde Westminister'da İskoçya için ayrılan 59 sandalyeden 56'sını alarak ne denli güçlü bir halk desteğine sahip olduğunu gösterirken, Londra'da İskoç çıkarlarının başlıca temsilcisi haline geldi. SNP’nin İskoçya'daki gelişimi, İş̧̧i Partisi'nin İskoçya'daki uzun süreli hâkimiyetini bitirmekle kalmadı ${ }^{60}, \mathrm{BK}$ seçimlerinin gösterdiği gibi İşçi Partisi’nin Londra’daki gücünün erozyona uğramasına da yol açtı. Dolayısıyla, İşçi Partisi’nin bugün içinde bulunduğu çalkantının nedenlerinden biri de SNP’nin İskoçya'daki yükselişi olmuştur. SNP’nin genel siyasete diğer etkisi, bir devlet-altı milliyetçi partinin Londra düzeyinde etkili bir aktöre dönüşmüş olmasıdır.

56 “Spain says it could”, The Guardian, 17 Eylül 2014, http://www.theguardian.com/politics/2014/sep/17/spainindependent-scotland-years-eu-membership (Erişim tarihi 12 Kasım 2015).

57 Referandum sonuçlarına ilişkin ayrıntılı bilgi için bkz. Electoral Commission, "Scottish Independence Referendum", Aralık 2014, http://www.electoralcommission.org.uk/_data/assets/pdf_file/0010/179812/Scottish-independencereferendum-report.pdf; Elections Scotland - Scottish Independence Referendum, http://scotlandreferendum.info/ (Erişim Tarihi 10 Aralık 2015).

58 Britanya'da genel oy hakkının hayata geçirildiği 1918'den bu yana yapılan tüm seçim ve referandumlar arasında \%84,5 ile katılım rekoru kırılmıştır, bkz. "Scottish independence: turnout record as 84\% vote", Scotsman, 19 Eylül 2014, http:// www.scotsman.com/news/politics/scottish-independence-turnout-record-as-84-vote-1-3546826 (Erişim Tarihi 10 Aralık 2015).

59 Lord Ashcroft Polls, “Scotland Independence Referendum”, http://lordashcroftpolls.com/2014/09/scotland-voted/ ; http://blog.whatscotlandthinks.org/2014/09/voted-yes-voted/ (Erişim Tarihi 10 Aralık 2015).

60 Bağımsızlık referandumu sürecinde, İskoç İşçi Partisiüye sayısı 13.000'e gerilerken, SNP üye sayısını25,000'den 112,000'e yükseltmiştir: "Independence referendum one year on: the winners and losers", Scotsman, 18 Eylül 2015, http://www. scotsman.com/lifestyle/independence-referendum-one-year-on-the-winners-and-losers-1-3891329\#axzz3q3Ex9rbS (Erişim Tarihi 11 Aralık 2015). 
SNP'nin genel seçimlerde elde ettiği başarı, partiye İskoçya'da hâkimiyetini güçlendirmesi için önemli bir fırsat sağlamıştır. Buna, referandum etkisiyle kurulan Smith Komisyonu raporu ${ }^{61}$ çerçevesinde, BK'nin İskoçya'ya yeni yetki devirleri yapmasının beklenmekte olduğu gerçeğini de ekleyecek olursak, İskoçya’da yeni bir bağımsızlık referandumu yapılması olasılığının hiç de düşük olmadığı anlaşılabilir. Dolayısıyla, 1970'lerde beri dile getirilen BK'nin birliği meselesi kritik bir dönemece gelmiş görünmektedir.

İmparatorluğun sona ermesi ile cazibesini yitirmeye başlayan, 1980'lerdeki neoliberal politikalarla tepki yaratan BK devleti de kendisini hedef alan SNP ve diğer devlet-altı milliyetçiliklere karşı, çeşitli önlemler geliştirmeye çalışmaktadır. Yetki devri hamlelerinin yanı sıra, erozyona uğrayan Britanyalı kimliğini canlandırmak için çaba harcanmaktadır. ${ }^{62}$ Ancak, bu noktada, belirtmek gerekir ki Britanyalı kimliğini erozyona uğratan sadece devlet-altı aktörlerin girişimleri değildir, yükselen devletaltı milliyetçiliklere karşı palazlanan İngiliz milliyetçiliği ${ }^{63}$ de BK'nin hayatta kalma çabalarını olumsuz etkileme potansiyeline sahiptir.

Tüm bu siyasi sarsıntılar içinde, BK'de sadece İskoç milliyetçiliğinin değil BK’nin geleceğini yakından ilgilendiren sarsıcı bir gelişme meydana geldi. 23 Haziran 2016'da gerçekleştirilen BK'nin $\mathrm{AB}$ üyeliğinin devam edip etmemesinin oylandığı referandumda (Brexit), halkın \%52'si AB üyeliğinin sona erdirilmesi yönünde oy kullandı. İskoçya özelinde ise halkın \%62'si AB'de kalınması yönünde irade gösterdi. Daha güçlü bir BK yaratma propagandası ile başarı kazanan Brexit taraftarlarına, SNP'nin tepkisi Brexit kampanyası sırasındaki pozisyonu ile uyumlu oldu.

Referandum öncesinde SNP liderliğindeki İskoç Hükümeti, BK AB'den çıkacak olursa İskoçya'nın ikinci kez bağımsızlık referandumu isteyeceğini açıklamış ve AB'den ayrılmanın genel referandum sonucunun yanı sıra, BK'yi oluşturan dört ulusun da ayrı ayrı aynı yönde irade göstermeleri gerektiğini ifade etmiştir. ${ }^{64}$ Referandum sonuçlarına göre $\mathrm{BK}, \mathrm{AB}$ 'den ayrılma müzakerelerine başlayacaktır; öte yandan, İskoç halkının önemli bir kısmı AB'de kalma yönünde irade beyan etmiştir. ${ }^{65} \mathrm{Bu}$ çerçevede İskoç Hükümeti, 2014 İskoç bağımsızlık referandumu sonrası koşulların Brexit nedeniyle somut ve önemli şekilde değiştiğini belirterek ikinci bir bağımsızlık referandumu talebini yinelemiştir.

61 Report of the Smith Commission, 27 Kasım 2014, https://www.smith-commission.scot/wp-content/uploads/2014/11/ The_Smith_Commission_Report-1.pdf(Erişim Tarihi 5 Aralık 2015).

62 İskoç halkının çoğu kendisini bugün de çift kimlikli olarak tanımlamaktadır. Kendisini sadece İskoç tanımlayan \%23, sadece Britanyalı olarak gören \%5'tir. Ancak, yıllar içinde kendini sadece İskoç tanımlayanların oranında istikrarlı olmasa da bir yükseliş gözlenmektedir, bkz. "Trends in National Identity”, British Social Attitudes, http://www.bsa.natcen.ac.uk/ latest-report/british-social-attitudes-30/devolution/trends-in-national-identity.aspx (Erişim Tarihi 1 Aralık 2015).

63 İngiliz milliyetçiliği İngiltere için özyönetim istemektedir. Britanyalı kimliğini dışlamayan bu hareket, "asimetrik” yetki devriyle ortaya çıkan haksızlıkların telafisini talep etmektedir. "West Lothian Sorunu" olarak ifade edilen duruma göre, yetki devrinden sonra Britanya Parlamentosu’nda İskoçya'yı temsilen yer alan İskoç milletvekili İskoçya'nın iç meseleleri hakkında oy hakkına sahip değildir, çünkü bu konudaki yetkiler İskoçya Parlamentosu'na devredilmiştir. Ancak aynı vekilin Britanya Parlamentosu’nun bir üyesi olarak İngiliz iç meseleleri hakkında oy hakkı devam etmektedir. Muhafazakâr güçlerin savunduğu İngiliz milliyetçiliği Britanya siyasetinde bir İngiliz boyutu yaratmak istemektedirler. Ancak bu taleplere ana akım partiler karşı çıkmaktadırlar. SNP'nin önceki lideri Salmond'a göre ise İngiliz Sorunu'nu ancak İskoçya’nın bağımsızlı̆̆ı çözebilir: "Only Scottish independence can solve the 'English Question”,', Telegraph, 20 Mart 2007, http://www.telegraph.co.uk/comment/personal-view/3638581/Only-Scottish-independence-can-solvethe-English-Question.html (Erişim Tarihi 30 Ekim 2015).

64 SNP 2015 Genel Seçim Bildirgesi, s.18-19, http://votesnp.com/docs/manifesto.pdf (Erişim Tarihi 19 Aralık 2015). SNP lideri bu taleplerini Brüksel ziyaretinde de dile getirmiştir: "EU referendum: Brussels delightened as”, Independent, 2 Haziran 2015 http://www.independent.co.uk/news/world/europe/eu-referendum-brussels-delighted-as-nicolasturgeon-warns-of-second-independence-vote-in-event-of-uk-10292979.html (Erişim Tarihi 10 Kasım 2015).

65 http://www.gov.scot/Topics/International/Europe/eu-referendum (Erişim Tarihi 15 Temmuz 2016). 
Kuşkusuz, Brexit uzun süredir birliğini çeşitli reformlar yoluyla korumaya çalışan BK merkezi yönetiminin işini daha da zorlaştıracaktır. Ancak, değişen koşulların SNP açısından da yeni zorluklar getirdiği görülmektedir. SNP "Avrupa içinde bağımsızlık" hedefi peşinde koşarken Maastricht Antlaşması'nın 49. değil 48. maddesi üzerinden hareket etmek istiyordu. Bunu yaparken de BK'nin AB'den elde ettiği hakları da korumayı amaçlıyordu. Oysa BK AB'den ayrılma müzakerelerine başladığında, SNP’nin “Avrupa içinde bağımsızlık” hedefi etrafında oluşturduğu söylem ve taleplerinin $A B$ nezdinde herhangi bir önceliği olmayacaktır. Bu durumda, SNP İskoçya'nın BK'den ayrılıp, AB'ye yeni üyelik başvurusu yapmasını savunmak zorunda kalabilir. Bu daha zorlu ve daha az avantajl yola, SNP'nin İskoç seçmenlerini ikna etmesi daha zor olacaktır. Ancak, olasılıkları bir yana koyduğumuzda, SNP’nin “Avrupa içinde bağımsızlık” hedefini devam ettirdiğini ve yakın gelecekte de bunun değişmesi için bir neden olmadığını kesin olarak söyleyebiliriz.

Son olarak, SNP önderliğindeki İskoç milliyetçiliği üzerine yaptığımız bu incelemeden şu genel sonuçlara ulaşabiliriz: İskoç milliyetçiliği BK'nin siyasal yapısında önemli değişikliklere neden olduğu gibi, BK'nin geleceği konusunda da ciddi bir belirsizlik yaratmaya devam etmektedir. Farklı milliyetçiliklerin mücadele sahası olarak görülebilecek Avrupa bütünleşme sürecinde yaratılan bazı ulusüstü yapılara karşın, ulus devletler AB'nin siyasal yapısında merkezi önemlerini devam ettirmektedirler. "Avrupa içinde bağımsızlık" hedefleyen SNP önderliğindeki İskoç milliyetçiliği de ulus-devlet fikri temelinde milliyetçiliğin kendini farklı formlarda ve farklı ideolojilerle eklemleyerek yeniden üretmede hala ne kadar başarılı olduğunu gösteren, genelde uluslararası ilişkiler, özelde Avrupa bütünleşmesi açısından kilit önemde bir rol oynamaya devam ettiğini kanıtlayan, dikkat çekici bir örnek oluşturmaktadır. 


\section{Kaynakça}

Aktoprak, Elçin. Devletler ve Ulusları, Tan Kitabevi Yayınları, Ankara, 2010.

BBCOneScotland,https://www.youtube.com/watch?v=33Z91-rWgfA(ZamanAralığı:1:18,15-1:18,52/1:29,02) (Erişim Tarihi, 18 Mart 2016).

Birch, Anthony. "Minority Nationalist Movements and Theories of Political Integration", World Politics, Cilt 30, No 3, Nisan 1978, s.325-44.

BK Hükümeti Hazine Bakanlığı Raporu. "Scotland Analysis: Currency and Monetary Policy”, Nisan 2013, s.69, https://www.gov.uk/government/uploads/system/uploads/attachment_data/file/191786/Scotland Analysis_acc-1.pdf (Erişim tarihi 18 Mart 2016).

Branch, Ann P. ve Jakob C. Ohrgaard, “Trapped in the Supranational-intergovernmental Dichotomy: A Response to Stone Sweet \& Sandholtz", Journal of European Public Policy, Cilt 6, No.1, s.123-43.

Breuilly, John. Nationalism and the State (2.Baskı), Manchester, Manchester University Press, 1993.

Brown, Alice et al. Politics and Society in Scotland, Basingstoke, Macmillan Press, 1998.

Catt, Helen ve Michael Murphy. Sub-State Nationalism: A Comparative Analysis of Institutional Design, Oxford \& New York, Routledge, 2002.

Crawford, James ve Alan Boyle. "Annex A Opinion: Referendum on the Independence of Scotland, International Law Aspects, https://www.gov.uk/government/uploads/system/uploads/attachment_data/file/79408/ Annex_A.pdf (Erişim Tarihi 1 Aralık 2015).

Dardanelli, Paolo. Between the Two Unions-Europeanisation and Scottish Devolution, Manchester University Press, Manchester, 2002.

De Winter, Lieven. "Conclusion: A Comparative Analysis of Electoral, Office, and Policy Success of Ethnoregionalist Parties", Lieven de Winter ve Huri Türsan (der.), Regionalist Parties in Western Europe, London \& New York, Routledge, 1998.

Dewdney, Richard. House of Commons Library, Social and General Statistics Section, Results of Devolution Referendums (1979 \& 1997), s.12, 10 Kasım 1997, file:///C:/Users/user/Downloads/RP97-113\%20(1). pdf (Erişim Tarihi, 14 Temmuz 2016).

Dickson, Tony. “Scotland is Different, OK?”. David McCrone et al. (der.), The Making of Scotland: Nation, Culture and Social Change, Great Britain, Edinburgh University Press, 1989.

Elections Scotland - Scottish Independence Referendum, http://scotlandreferendum.info/ (Erişim Tarihi 10 Aralık 2015).

Electoral Commission, "Scottish Independence Referendum", Aralı 2014, http://www.electoralcommission. org.uk/_data/assets/pdf_file/0010/179812/Scottish-independence-referendum-report.pdf.

European Free Alliance, http://www.e-f-a.org/home/.

"Former NATO commander attacks SNP defence policy", BBC News, 31 Ağustos 2014, http://www.bbc.com/ news/uk-scotland-scotland-politics-29005808 (Erişim Tarihi 18 Mart 2016).

Harvie, Christopher. Scotland-A Short History, Oxford, Oxford University Press, 2014.

Hobsbawm, Eric J. Milletler ve Milliyetçilik (3.Basım), Ayrıntı Yayınları, İstanbul, 2006.

Hooghe, Liesbet. "Nationalist Movements and Social Factors: A Theoretical Perspective", John W. Coakley (der.), The Social Origins of Nationalist Movements: The Contemporary West European Experience, London, Sage, 1992, s.21-44.

Hoppe, Marcus. "Sub-state Nationalism and European Integration: Constructing Identity in the Multilevel Political Space of Europe”, Journal of Contemporary European Research, Cilt 1, No 2, 2005, s.13-28.

Houten, Pieter van. "Regional Assertiveness in Western Europe - A Statistical Exploration", April 2001, Grenoble, s.16, https://ecpr.eu/Filestore/PaperProposal/11d561d0-664a-4973-a424-91ce46fce5de.pdf , (Erişim Tarihi 15 Ekim 2015). 
Ichijo, Atsuko. Scottish Nationalism and the Idea of Europe, Oxon \& New York, Routledge, 2004.

"Independence referendum one year on: the winners and losers", Scotsman, 18 Eylül 2015, http:// www.scotsman.com/lifestyle/independence-referendum-one-year-on-the-winners-and-losers-13891329\#axzz3q3Ex9rbS (Erişim Tarihi 11 Aralık 2015).

Judge, David. Political Institutions in the United Kingdom, Oxford \& New York, Oxford University Press, 2005.

Katalonya Parlamentosu, http://catalanassembly.org/en/catalonia-said-yes-to-independence/ (Erişim Tarihi 12 Kasim 2015).

Keating, Michael. Nations against the State: the New Politics of Nationalism in Quebec, Catalonia, and Scotland, London, Macmillan, 1996.

Lindsay, Isobel. “The SNP and the Lure of Europe”, Tom Gallagher (der.), Nationalism in the Nineties, Edinburgh, Polygon, 1991.

Lord Ashcroft Polls, "Scotland Independence Referendum", http://lordashcroftpolls.com/2014/09/scotlandvoted/ ; http://blog.whatscotlandthinks.org/2014/09/voted-yes-voted/ (Erişim Tarihi 10 Aralık 2015).

Loughlin, John. "Introduction: The Transformation of the Democratic State in Western Europe”, John Loughlin (der.), Subnational Democracy in the European Union, Oxford \& New York, Oxford University Press, 2001.

Lynch, Peter. Minority Nationalism and European Integration, Cardiff, University of Wales Press, 1996.

Lynch, Peter. The History of the Scottish National Party, Wales, Welsh Academic Press, 2002.

Mitchell, James. "Member State or Euro-Region? The SNP, Plaid Cymru, and Europe”, David Baker ve David Seawright (der.), Britain For and Against Europe, Oxford, Clarendon Press, 1998.

McAdam, Doug et al. "Introduction: Opportunities, Mobilizing Structures, and Framing Processes - toward a Synthetic, Comparative Perspective on Social Movements”. Doug McAdam et al. (der.), Comparative Perspectives on Social Movements, Cambridge, Cambridge University Press, 1996, s.1-20.

Moravcsik, Andrew ve Frank Schimmelfennig. “Liberal Intergovernmentalism”, Antje Wiener ve Thomas Diez (der.), European Integration Theory, Oxford, Oxford UP, 2009, s.67-90.

Nairn, Tom. The Break-up of Britain: Crisis and Neo-Nationalism, London, Verso, 1977.

Ohrgaard, Jakob C. "Less Than Supranational, More Than Intergovernmental: European Political Cooperation and the Dynamics of Intergovernmental Integration”, Millennium - Journal of International Studies, Cilt 26, No.1, s.1-29.

“Only Scottish independence can solve the 'English Question”, Telegraph, 20 Mart 2007, http://www.telegraph. co.uk/comment/personal-view/3638581/Only-Scottish-independence-can-solve-the-English-Question. html (Erişim Tarihi 30 Ekim 2015).

Özkırımlı, Umut. Milliyetçilik Kuramları - Eleştirel Bir Bakış, DoğuBatı Yayınevi, Ankara, 2008.

Report of the Smith Commission, 27 Kasim 2014, https://www.smith-commission.scot/wp-content/ uploads/2014/11/The_Smith_Commission_Report-1.pdf (Erişim Tarihi 5 Aralık 2015).

Rosamond, Rosamond. Theories of European Integration, Hampshire \& NY, Palgrave, 2000.

Saylan, İbrahim. Sub-state Nationalism within European Integration Process: A Comparative Study of Scottish, Basque and Kurdish Cases, Yayınlanmamıs Doktora Tezi, Ankara, Bilkent Üniversitesi, Ekonomi ve Sosyal Bilimler Enstitüsü, 2011.

“Scotland in numbers", BBC News, 25 Kasım 2013, http://www.bbc.com/news/uk-scotland-24866266 (Erişim Tarihi 1 Aralık 2015).

"Scottish independence: turnout record as 84\% vote", Scotsman, 19 Eylül 2014, http://www.scotsman.com/ news/politics/scottish-independence-turnout-record-as-84-vote-1-3546826 (Erişim Tarihi 10 Aralık 2015).

"Scottish independence: Barroso says joining EU would be 'difficult”, BBC News, 16 Şubat 2014, http://www. bbc.com/news/uk-scotland-scotland-politics-26215963 (Erişim tarihi 9 Kasım 2015). 
Scottish Government Report 2013, Scotland in the European Union, http://www.gov.scot/Resource/ 0043/00439166.pdf (Erişim Tarihi 9 Kasım 2015), s.12 ve s.14-17.

SNP 1997 Genel Seçim Bildirgesi, http://www.politicsresources.net/area/uk/ge97/man/snp97.pdf (Erişim Tarihi, 15 Aralık 2015).

SNP 2010 Genel Seçim Bildirgesi, http://www.politicsresources.net/area/uk/ge10/man/parties/SNP.pdf (Erişim Tarihi, 10 Aralık 2015).

SNP 2011 İskoçya Seçimleri Seçim Bildirgesi, http://votesnp.com/campaigns/SNP_Manifesto_2011_ lowRes.pdf.

SNP Declarations, http://votesnp.com/campaigns/SNP_Manifesto_2011_lowRes.pdf (Erişim Tarihi 15 Aralık 2015).

SNP Declarations, http://www.snpcnd.org/index.php?subaction=showfull\&id=1443732206\&archive=\&sta rt_from $=\& u c a t=\&($ Erişim Tarihi 21 Aralık 2015).

"SNP accused of ", The Guardian, 20 Ağustos 2014, http://www.theguardian.com/business/2014/aug/20/ snp-accused-exaggerating-north-sea-oil-reserves (Erişim Tarihi 19 Mart 2016).

"SNP tells Madrid", The Herald Scotland, 20 Eylül 2015, http://www.heraldscotland.com/news/13771674. SNP_tells_Madrid_allow_Catalonia_an_independence_referendum/ (Erişim Tarihi $9 \mathrm{Kasım} 2015$ ).

"Spain says it could", The Guardian, 17 Eylül 2014, http://www.theguardian.com/politics/2014/sep/17/spainindependent-scotland-years-eu-membership (Erişim tarihi 12 Kasım 2015).

Stone Sweet, Alec ve Wayne Sandholtz. "European Integration and Supranational Governance", Journal of European Public Policy, Cilt 4, No.3, Eylül 1997, s.297-317.

The Scottish Government, Government Expenditure and Revenue Scotland, http://www.gov.scot/Topics/ Statistics/Browse/Economy/GERS.

The Brookings Institution, http://www.brookings.edu/ /media/events/2013/4/09\%20scotland/20130409_ scotland_salmond_transcript.pdf (Erişim Tarihi, 10 Kasım 2015).

The SNP, Scotland: A European Nation, Edinburgh, 1992.

The Scottish Government, Scotland's Future - Your Guide to an Independent Scotland, 2013, http://www.gov. scot/resource/0043/00439021.pdf

TheScottish Government, TheScottish IndependenceBill,2014,http://www.gov.scot/resource/0045/00452762. pdf (Erişim Tarihi 8 Aralık 2015). “Trends in National Identity”, British Social Attitudes, http://www.bsa. natcen.ac.uk/latest-report/british-social-attitudes-30/devolution/trends-in-national-identity.aspx (Erişim Tarihi 1 Aralık 2015).

"Unionists urged to sign EU letter", The Herald Scotland, 31 Ocak, 2013, http://www.heraldscotland.com/ news/13090395.Unionists_urged_to_sign_EU_letter/ (Erişim Tarihi 9 Kasım 2015).

Yes Scotland, http://b.3cdn.net/better/8e048b7c5f09e96602_jem6bc28d.pdf (Erişim Tarihi 8 Aralık 2015). 